\title{
Analysis of Voltage Sag Due to Short Circuit on the Sub System in Central Sumatera
}

\author{
Hendry \\ Electrical Engineering Department, \\ Universitas Lancang Kuning \\ Pekanbaru, Indonesia
}

\author{
*Hamzah Eteruddin \\ Electrical Engineering Department, \\ Universitas Lancang Kuning \\ Pekanbaru, Indonesia
}

\author{
Atmam \\ Electrical Engineering Department, \\ Universitas Lancang Kuning \\ Pekanbaru, Indonesia
}

*corresponding author: Hamzah Eteruddin hamzah@unilak.ac.id

\begin{abstract}
Power quality is closely related to electrical energy which is directly related to voltage and current interference. Electrical equipment used daily requires good power quality. The thing that affects the quality of the power is the voltage dip. Based on the IEEE 1159-1995 standard, voltage sag is a decrease in RMS voltage with duration of 0.5 cycle to 1 minute. Sag voltage that occurs can have an effect on electronic equipment and other problems that often arise in the industrial environment. Therefore, a short circuit fault analysis was conducted to determine the voltage sag based on the type of fault in the sub system in Central Sumatera. Short circuit fault analysis is done using Power world Simulator 7.0 Students Edition. This study is intended to determine the sag voltage when there is a short circuit fault. The biggest voltage sag occurs when a short circuit fault of single phase to ground at $75 \%$ fault location and the smallest voltage sag when the three-phase short circuit of 0.7 fault location.
\end{abstract}

Keywords-Power quality, Short circuit, Voltage sag.

\section{INTRODUCTION}

Good electrical power quality is a very important contribution to human life, in the modern century as it is now a very vital role in the fields of telecommunications, information technology, industry, education, and others. Power quality is usually related to a disturbance that occurs in voltage, current, and frequency. Power quality is a big concern for suppliers and consumers. The effect is caused by a lack of power quality felt in some countries, where billions of dollars were spent only to improve poor power quality. The main reason is that some industries do not wish to renew their plants. Over the past few years ago, the power quality has been a problem that was discussed throughout the country. The main problem is the sensitivity of electrical equipment related to power quality is lower than before. Some of the problems that affected on power quality are voltage dip (sag), swell (increase in voltage amplitude), interruption (loss of amplitude), harmonics and frequency variations [1]. Voltage sag is a phenomenon of Root Mean Square (RMS) voltage reduction in a short time during short circuit conditions, overloads, and starting large-capacity motors [1]. Attention to sag voltage is quite large because it can cause damage to some sensitive equipment such as adjustable-speed drives, process-control equipment, and computers. Some parts of the equipment will trip if the RMS voltage is below $90 \%$ for a time of more than one or two cycles [2]. Voltage sag can occur during short circuits conditions hundreds of time from several kilometers away on an electric power transmission system. Disruption of short circuits such as 1 phase to ground, phases and 3 phases is a frequent interference, although this interference is temporary and lasts relatively short, this event can cause a momentary voltage drop. Voltage sag (dip) is a decrease in RMS voltage with duration of 0.5 cycles for 1 minute [3].

\section{LITERATURE REVIEW}

\section{A. Power Quality}

The term power quality is commonly used in the recent years in the field of electric power systems. Sag voltage is a part of the power quality problems, which also known as the dip [4]. Power quality could interpret as the ability to meet electrical energy needs without interruption. Power quality is a global issue that is a major concern for suppliers and customers [5]. Power quality problems have a variety of different problems. Each problem has a variety of different causes and different solutions that be used to improve power quality and equipment performance [5]. Some of the problems that affected to power quality are voltage sag, voltage increase, interruption, transient, flicker, harmonics and frequency variations. These problems can have an effect on consumer equipment, damage, and losses due to loss of production [6]. 


\section{B. Voltage Sag}

Definition of voltage sag based on the IEEE 11591995 standard is reduction of rms voltage for a short duration to an extent between 0.1 and $0.9 \mathrm{pu}[7,8]$. Duration of sag is seen in between 0.5 cycles and $1 \mathrm{~min}$. Sag is often called as voltage dip. In Figure 1, voltage sag occurs and returns to normal after 0.12 seconds [2]. Measurement of voltage sag to $\mathrm{x}$ (volts or percent) is given in the percentage or also called sag to, voltage sag to $60 \%$ is equal to $60 \%$ of nominal voltage or 288 Volt to 480 Volt in the system [9]. Voltage sag is generally understood as the amount where the nominal voltage decreases in percentage. Thus, the voltage that is positioned $40 \%$ is equal to Voltage Sag to $60 \%$ [10].

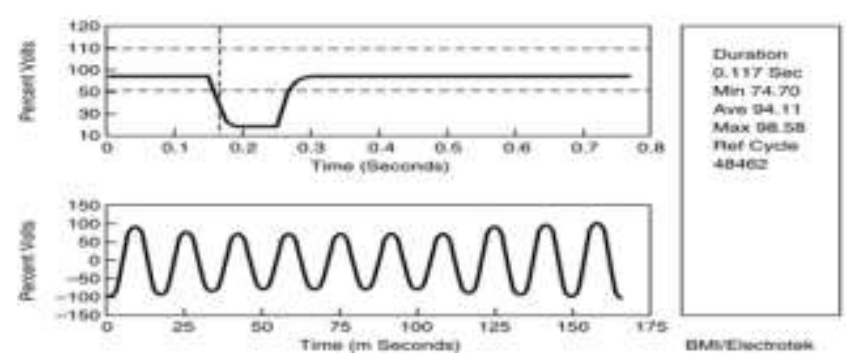

Figure 1: Voltage sag plot [2].

Voltage sag could occur on distribution and transmission lines. Voltage sag that occurs at high voltage will spread to utility systems and will transmitted to a low voltage system via a transformer, as in Figure 2 [10].

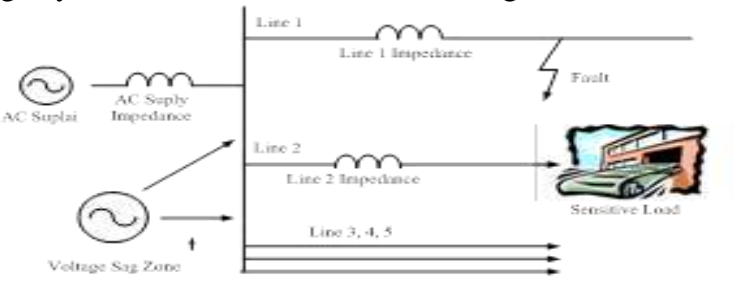

Figure 2: Modeling of voltage sag affected to the systems [10].

Voltage sag can appear in an industry, in general, there are two causes of voltage sag, which is due to a fault in the system and the ignition of a large power induction motor. Obtaining the voltage sag obtain single phase to ground fault occurs, by the following equation [11].

\section{1) Positive Sequence Voltage}

Positive sequence voltage has single phase to ground fault obtained by using the following equation [11].

$V_{+ \text {real }}=V_{\text {bus }}-\left(\frac{I_{L-G}}{3}\right) \times Z_{1 J A R} \times \cos \theta$

$V_{+i m j}=0-\left(\frac{I_{L-G}}{3}\right) \times Z_{1 J A R} \times \sin \theta$

\section{2) Negative Sequence Voltage}

Negative sequence voltage has single phase to ground fault obtained by using the following equation [11].

$$
\begin{aligned}
& V_{- \text {real }}=-\left(\frac{I_{L-G}}{3}\right) \times Z_{2 J A R} \times \cos \theta \\
& V_{-i m j}=-\left(\frac{I_{L-G}}{3}\right) \times Z_{2 J A R} \times \sin \theta
\end{aligned}
$$

\section{3) Zero Sequence Voltage}

Zero sequence voltage on single phase to ground fault is obtained using the following equation [11].

$V_{0 \text { real }}=-\left(\frac{I_{L-G}}{3}\right) \times Z_{0 J A R} \times \cos \theta$

$V_{0 i m j}=-\left(\frac{I_{L-G}}{3}\right) \times Z_{0 J A R} \times \sin \theta$

Then the voltage dip when the single line to ground short circuit uses the following equation [11].

$V_{\text {Sag } 1 \phi}=\sqrt{\left(\Delta V_{\text {real }}\right)^{2}+\left(\Delta V_{i m j}\right)^{2}} \angle \tan ^{-1}\left(\frac{\Delta V_{i m j}}{\Delta V_{\text {real }}}\right)$

Where

$\Delta V_{\text {real }}=V_{+ \text {real }}+V_{- \text {real }}+V_{0 \text { real }}$
$\Delta V_{i m j}=V_{+i m j}+V_{-i m j}+V_{0 i m j}$

\section{RESEARCH METHODOLOGY}

The research methodology conducted in this study is shown in Figure 3.

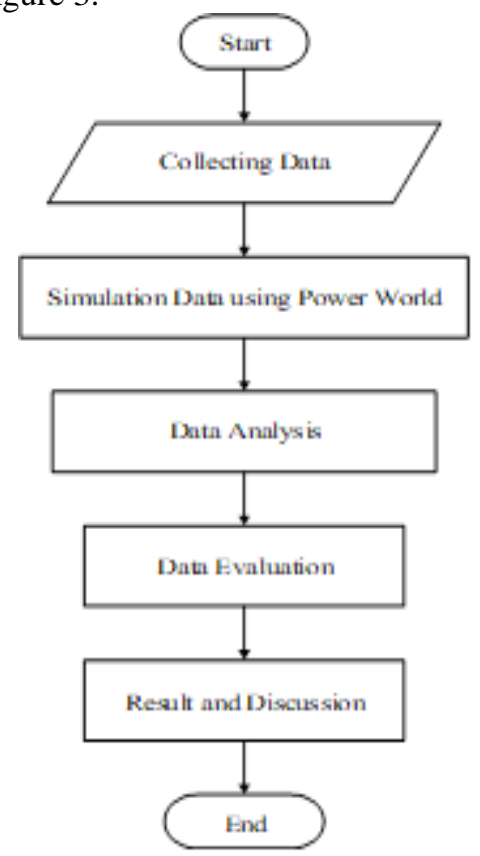

Figure 3: Research flowchart.

\section{RESULTS AND DISCUSSION}

PT. PLN (Persero) Electric power transmission sub system Central Sumatera supplied by Hydroelectric Power Plants, Steam Power Plants, Combined Cycle Power Plant, Diesel Power Plants, Gas Power Plants, and Gas Engine Power Plants. System is connected by $150 \mathrm{kV}$ over headline high voltage transmission system, to deliver excessive power in one region to another region that lacks power. There are in addition power generation units that supply power to the region's subsystem to meet the power needs of each region. The Central Sumatera sub system Load Management Unit is one of the units of PT. PLN (Persero) in charge of managing the operation of the electric power system in West Sumatera, Riau and Jambi. 
Central Sumatera sub system Single Line as showed in Figure 4 . This research begins by calculating the line impedance at the point of interference of $5 \%, 10 \%, 25 \%$, and $75 \%$ of the $150 \mathrm{kV}$ over head high voltage system. Especially at the Balai Pungut to Duri, Singkarak to Lubuk Alung and Payoselincah-Aur Duri. Then, process simulates the short circuit current on single phase to ground and three phases by using the Powerworld Simulator 7.0 Students Edition program. After obtaining the results of impedance and short circuit fault current, a calculation performed to de termine the voltage sag when a fault occurs.

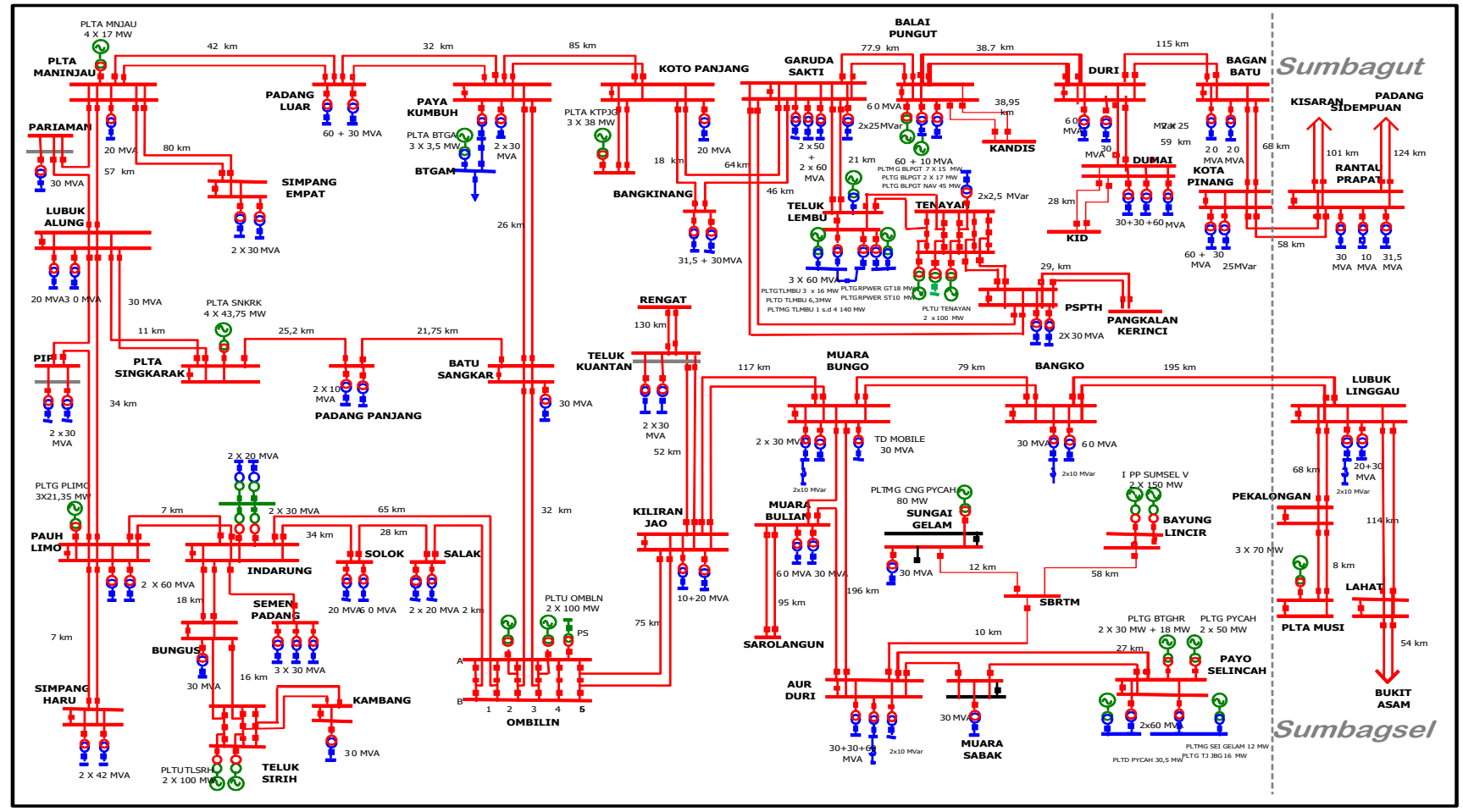

Figure 4: Single line diagram of sub system in Central Sumatera

\section{A. Voltage Sag on Balai Pungut - Duri}

Voltage sag is obtained based on the value of short circuit and in this study using Powerworld Simulator 7.0 Students Edition program. Fault location at the line of $5 \%, 10 \%$, $25 \%$, and $75 \%$ then the results are as showed in Table 1. The comparison graph of the Voltage Sag of the Balai Pungut-Duri when single phase to ground and three phases fault as showed in Figure 5.
Table 1: Voltage sag on Balai Pungut-Duri lines caused by single phase to ground and three phase faults

\begin{tabular}{|c|c|c|}
\hline $\begin{array}{c}\text { Fault } \\
\text { Location }\end{array}$ & $\begin{array}{c}\text { Single Phase to } \\
\text { Ground }\end{array}$ & Three Phase \\
\hline $5 \%$ & $49.059,79 \angle 0,73^{\circ}$ & $3.474,62 \angle-88,05^{\circ}$ \\
\hline $10 \%$ & $48.153,65 \angle 1,42^{\circ}$ & $6.808,70 \angle-88,20^{\circ}$ \\
\hline $25 \%$ & $45.737,66 \angle 3,50^{\circ}$ & $16.152,17 \angle-88,55^{\circ}$ \\
\hline $75 \%$ & $39.348,00 \angle 10,95^{\circ}$ & $44.087,55 \angle-88,77^{\circ}$ \\
\hline
\end{tabular}

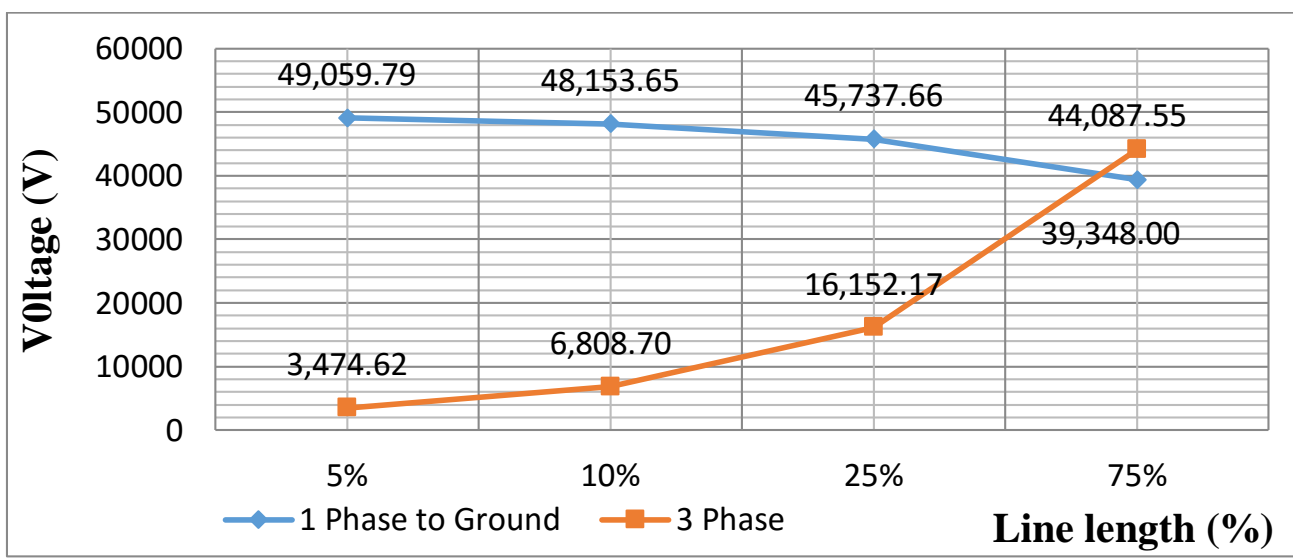

Figure 5: Comparison chart of voltage sag on Balai Pungut - Duri lines. 


\section{B. Voltage Sag on Singkarak-Lubuk Alung}

Voltage sag when there is a short circuit single phase to ground and three phase short circuit fault at 5\%, 10\%, $25 \%$, and $75 \%$ at Singkarak-Lubuk Alung. Then, the comparison voltage sag at Singkarak and Lubuk Alung as shown in Table 2. Graph of the voltage of the SingkarakLubuk Alung voltage when single phase to ground and three phases fault as shown in Figure 6.
Table 2: Singkarak-Lubuk Alung voltage sag

\begin{tabular}{|c|c|c|}
\hline $\begin{array}{c}\text { Fault } \\
\text { Location }\end{array}$ & $\begin{array}{c}\text { Single Phase to } \\
\text { Ground }\end{array}$ & Three Phase \\
\hline $5 \%$ & $49.747,50 \angle 0,29 \mathrm{o}$ & $668,08 \angle-81,18 \mathrm{o}$ \\
\hline $10 \%$ & $49.499,24 \angle 0,58 \mathrm{o}$ & $1.331,44 \angle-81,24 \mathrm{o}$ \\
\hline $25 \%$ & $48.773,65 \angle 1,47 \mathrm{o}$ & $3.307,15 \angle-81,40 \mathrm{o}$ \\
\hline $75 \%$ & $46.389,84 \angle 4,77 \mathrm{o}$ & $10.153,89 \angle-88,60 \mathrm{o}$ \\
\hline
\end{tabular}

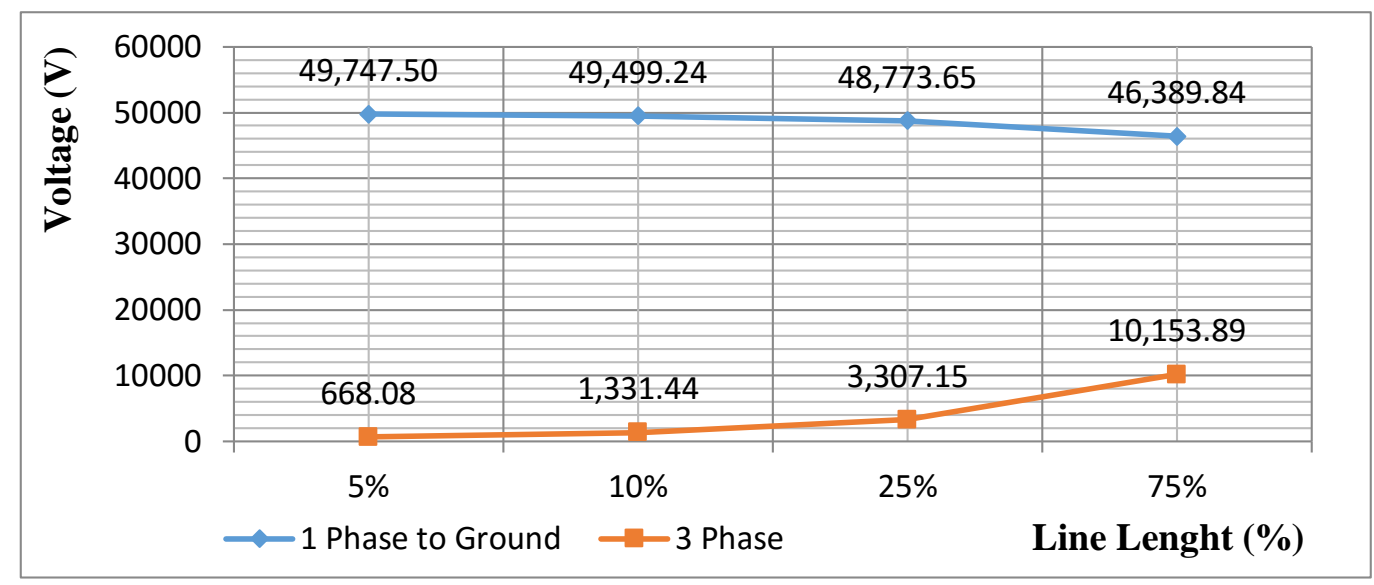

Figure 6: Comparison graph of voltage sag on Singkarak-Lubuk Alung lines

\section{Voltage Sag on Payoselincah-Aur Duri}

There is a short circuit single phase to ground and three phase short circuit fault at the $5 \%, 10 \%, 25 \%$, and $75 \%$ of the line. Then, comparison of voltage sag at Payoselincah and Aur Duri as shown in Table 3. Graph of the voltage sag of Payoselincah-Aur Duri when single phase to ground and three phases fault as shown in figure 7.
Table 3: Voltage Sag on Payo Silincah-Aur Duri lines

\begin{tabular}{|c|c|c|}
\hline $\begin{array}{c}\text { Fault } \\
\text { Location }\end{array}$ & 1 Phase to Ground & 3 Phasa \\
\hline $5 \%$ & $48.573,24 \angle-0,58^{\circ}$ & $1.911,37 \angle-45,89^{\circ}$ \\
\hline $10 \%$ & $47.180,62 \angle-1,19^{\circ}$ & $3.798,33 \angle-45,89^{\circ}$ \\
\hline $25 \%$ & $43.165,76 \angle-3,21^{\circ}$ & $9.356,98 \angle-45,89^{\circ}$ \\
\hline $75 \%$ & $30.607,52 \angle-13,70^{\circ}$ & $28.002,26 \angle-45,89^{\circ}$ \\
\hline
\end{tabular}

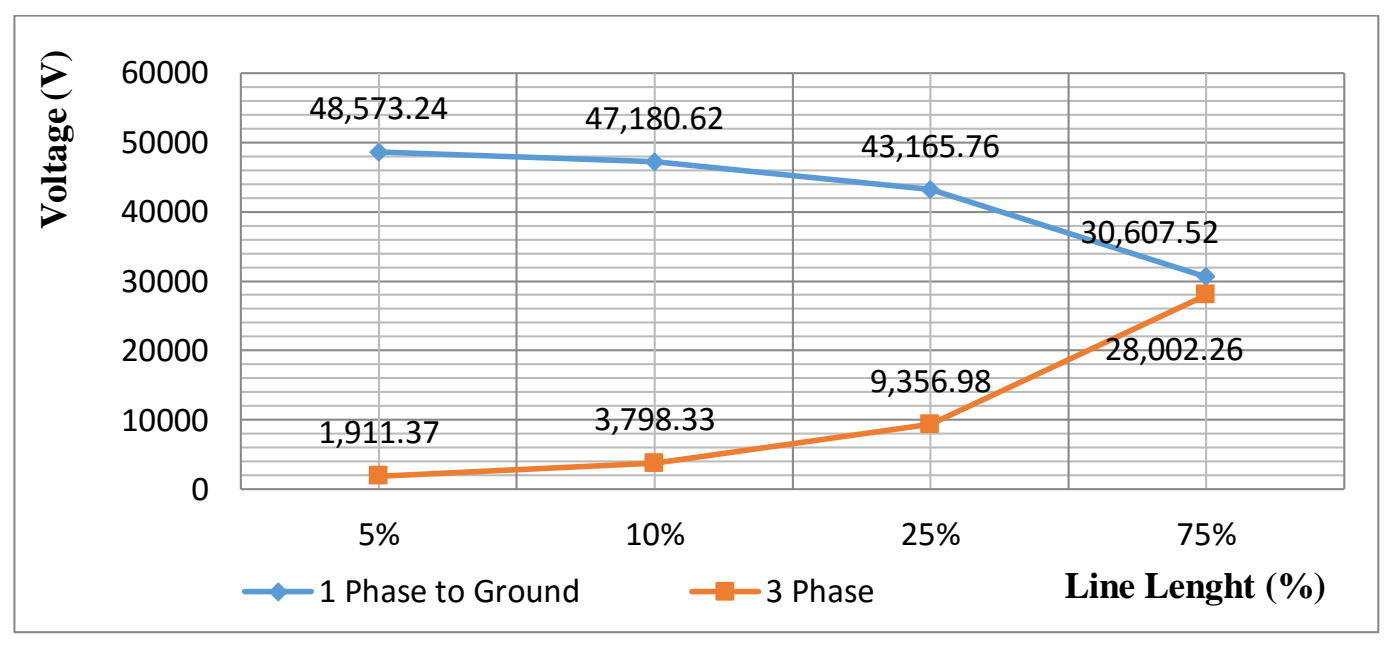

Figure 7: Comparison graph of the voltage sag on Payoselincah-Aur Duri lines 


\section{CONCLUSION}

The Voltage Sag when there is a single line to ground short circuit on Balai Pungut-Duri at 5\%, 10\%, 25\% and $75 \%$ of the line are $49.059 .79 \mathrm{~V}, 48,153.65 \mathrm{~V}, 45,737,66 \mathrm{~V}$, and $39,348.00 \mathrm{~V}$. The voltage sag when three phase short circuit occurs at $5 \%, 10 \%, 25 \%$ and $75 \%$ of the line are 3,474.62 V, 6,808.70 V, $16.152 .17 \mathrm{~V}$, and $44,087.55 \mathrm{~V}$ respectively. a single line to ground short circuit on the Singkarak - Lubuk Alung line at 5\%, 10\%, 25\% and $75 \%$ of the line are $49,747.50 \mathrm{~V}, 49,499.24 \mathrm{~V}, 48,773,65 \mathrm{~V}$, and $46,389.84 \mathrm{~V}$. the three phase short circuit fault occur at at $5 \%, 10 \%, 25 \%$ and $75 \%$ of the line are $668.08 \mathrm{~V}, 1.331 .44$ $\mathrm{V}, 3,307.15 \mathrm{~V}$, and $10,153.89 \mathrm{~V}$. Then, there is a single line to ground short circuit on the Payoselincah - Aur Duri at $5 \%, 10 \%, 25 \%$ and $75 \%$ of the line are $48,573.24 \mathrm{~V}$, $47,180.62 \mathrm{~V}, 43,165.76 \mathrm{~V}$, and $30,607.52 \mathrm{~V}$ respectively. While the Voltage Sag when the three phase short circuit fault at $5 \%, 10 \%, 25 \%$ and $75 \%$ of the line are $1,911.37 \mathrm{~V}$, $3,798.33 \mathrm{~V}, 9,356.98 \mathrm{~V}$, and $28,002.26 \mathrm{~V}$ respectively. The biggest percentage voltage sag is then that there is a single line to the ground short circuit fault occurs on Balai PungutDuri, Singkarak - Lubuk Alung and Payoselincah - Aur Duri line is at the $75 \%$. The smallest voltage sag is $5 \%$ fault location. The biggest percentage of voltage sag when there are a three phase short circuits in the Balai Pungut-Duri, Singkarak-Lubuk Alung and Payoselincah-Aur Duri line is at the 5\% fault location and the smallest Voltage Sag is at the $75 \%$.

\section{REFERENCES}

[1] M. H. J, "Bollen, Understanding Power Quality Problems, Voltage Sag and Interruptions", John Wiley, New York, 2000.

[2] B. W. Kennedy, "Power Quality Primer. New York", McGraw-Hill, 2000.

[3] R. S. Vedam, M. S. Sarma, "Power Quality: VAR Compensation in Power Systems", CRC Press, London, 2009.

[4] M. N. Sinha, B.R.Parekh, "Simulation of Voltage Sag Magnitude Estimation in a Power System Network," Res. Rev. - Int. Journals Int. J. Adv. Res. Electr. Electron. Instrum. Eng., vol. 3, no. 2, pp. 74107415, 2014.

[5] R. C. Dugan, S. Santoso, M. F. McGranaghan, H. W. Beaty, "Electrical Power Systems Quality", 2nd ed. McGraw-Hill Education, 2002.

[6] A. Chowdhury and D. Koval, "Power Distribution System Reliability: Practical Methods and Applications", Wiley, New Jersey, 2011.

[7] IEEE and Institute of Electrical and Electronic Engineers, "IEEE Std 1159 - IEEE Recommended Practice for Monitoring Electric Power Quality", 2009.

[8] L. Zhang and M. H. J. Bollen, "A method for characterisation of three-phase unbalanced dips (sags) from recorded voltage waveshapes", 21st International Telecommunications Energy Conference. INTELEC '99 (Cat. No.99CH37007), p. 188, 1999.

[9] R. K. Sinha, R. Kumar, M. Venmathi, L. Ramesh, "Analysis of Voltage Sag with Different DG for Various Faulty Conditions,” Int. J. Comput. Commun. Inf. Syst., vol. 2, no. 1, pp. 189-193, 2010.

[10] I. K. P. Ross, "Voltage Sags an Explanation Causes, Effects, and Correction", 2006.

[11] C. L. Wadhwa, "Electrical Power System", New Academic Science, 2012. 